\title{
International health law: an emerging field of public international law
}

\author{
Brigit Toebes (i)
}

Published online: 6 April 2016

(C) The Author(s) 2016. This article is published with open access at Springerlink.com

\begin{abstract}
This article discusses the nature and scope of international health law as an emerging field of public international law. It is argued that the protection of health reflects a pressing social need that should now be spoken of in the vocabulary of international law. Furthermore, there is an urgent need for counterbalancing interests such as international trade, global commerce and the welfare interests of the protection of the health of both individuals and populations worldwide. As of now, international health law is not a well-developed field. The health-related standardsetting legal instruments are very fragmented as there is no overall international recognition of international health law as a distinct branch of international law. Enormous challenges lie ahead, especially in terms of strengthening the existing instruments and addressing the responsibilities of non-state actors in the health field.
\end{abstract}

Keywords International health law · Right to health · Public health · Globalization · Standard-setting

\section{Introduction}

Ongoing globalisation has implications not only for the world's economies, but it also seriously impacts on the health of both populations and individuals worldwide. ${ }^{1}$ It poses a number of important challenges to

1 Tikki Pang \& G Emmanuel Guindon, Globalization and risks to health, 5(Suppl 1) EMBO Rep (October 2004) S11-S16.

Prof Dr Brigit Toebes is Rosalind Franklin Fellow at the University of Groningen. The author is thankful to Dr André de Hoogh and Dr Panos Merkouris for comments to an earlier version of this article.

Brigit Toebes $(\bowtie)$

Faculty of Law, University of Groningen, Groningen, The Netherlands

e-mail: b.c.a.toebes@rug.nl 
the health field, demanding both national and international responses. ${ }^{2}$ Traditionally, such international responses have focused on limiting the spread of infectious diseases. While the recent Ebola crisis has demonstrated that infectious diseases continue to pose a serious threat to global health, there are new and different global health challenges that need to be met as well, including the global rise in non-communicable (chronic) diseases. ${ }^{3}$ Public health research indicates that health inequalities within and between nations are increasing, ${ }^{4}$ and many countries continue to struggle with the detrimental health effects of environmental degradation, climate change, urbanisation and internal conflicts. ${ }^{5}$ International trade and the growing influence of multinational corporations have resulted in changes in disease patterns, some of which are lifestylerelated. $^{6}$ As a result of these developments, attention to global health should be directed not only at the spread of infectious diseases but also at, for example, global and domestic health inequalities, issues concerning access to healthcare and medicines, and the care for health in international and national emergencies and armed conflicts. ${ }^{7}$

This contribution is aimed at analysing and discussing the scope of international health law as an emerging branch of public international law. ${ }^{8}$ Contrary to, for example, international trade law, international environmental law and international humanitarian law, international health law is not a well-developed field. This article will advance the idea that health equity, fairness in health or the 'capability to be healthy' is a key value that forms a core component of the human dignity of individuals. Health equity, or health justice, is currently not sufficiently emphasised in public international law as compared to, for example, international trade and humanitarian law. This article asserts that health equity and the protection of health need to be placed more firmly on the international law agenda so as to be able to balance the interests of

\footnotetext{
2 See also the comprehensive article by Lawrence O Gostin \& Allyn L Taylor, Global Health Law: A Definition and Grand Challenges, 1(1) Pub Health Ethics (2008) 53-63.

${ }^{3}$ WHO, Non-communicable diseases <http://www.who.int/mediacentre/factsheets/fs $355 /$ en $/>$. Accessed November 2015.

${ }^{4}$ WHO, Commission on the Social Determinants of Health, Closing the Gap in a Generation, Health Equity through Action on the Social Determinants of Health (WHO, Geneva, 2008).

${ }^{5}$ See, World Bank, The Climate Change, Environment and Natural Resources Management <http:/ / web.worldbank.org/WBSITE/EXTERNAL/WBI/WBIPROGRAMS/ENRLP/0,,contentMDK:2024 $2344 \sim$ pagePK:64156158 piPK:64152884 theSitePK:460957,00.html> accessed November 2015.

${ }^{6} \mathrm{WHO}$, non-communicable diseases, see supra note 4.

7 See also, Gostin \& Taylor, 2008, supra note 2, 53-63.

8 See also, Michel Bélanger, Une nouvelle branche du droit international: le droit international de la santé, Etudes internationals Québec (1982) 611-632.
} 
trade, economic growth and warfare against the protection of the health of individuals and groups.

International standard-setting instruments are, increasingly, successfully employed by international organisations, state authorities and civil society organisations to achieve fairness in health. For instance, the Framework Convention on Tobacco Control (FCTC) has played a key role in several domestic court cases. However, as mentioned, there is currently no overarching international recognition of international health law as a distinct field of public international law.

In an attempt to create clarity in the field, this article focuses on the rationale, the sources, the scope and the responsible actors for international health law (sections $2-5$, respectively). When it comes to the sources of international health law, this article will address the most important standard-setting instruments under this branch of international law. These instruments vary from legally binding instruments (FCTC and International Health Regulations), to legally binding norms (right to health and other human rights norms), to authoritative yet non-binding instruments World Health Organisation (the WHO) recommendations and General Comments under human rights law).

Globalisation only adds a number of new actors to our analysis in addition to the international society of states, including multinational corporations, non-governmental organisations and public-private partnerships. As international law is still primarily state-centred, it fails to call these actors to account directly. ${ }^{9}$ To accommodate these developments, certain authors have argued in favour of the term 'global health law. ${ }^{10}$ While this approach makes a great deal of sense for the abovementioned reason, this terminology is not congruent with the terms used to address other branches of international law (e.g. international trade law, international environmental law and international humanitarian law). To emphasise the public international law dimension and to avoid a deviation from existing terminology, this article will use the term 'international health law' to identify the disciplinary nature of this field. As with the other existing branches of international law, the

\footnotetext{
${ }^{9}$ Gostin \& Taylor, supra note 2, 53-63.

${ }^{10}$ For an authoritative study, see Lawrence O Gostin, Global Health Law (Harvard Univ Press, Cambridge, 2014); Obijofor Aginam, Global Health Governance: International Law and Public Health in a Divided World (Toronto: University of Toronto Press, 2005); Michel Bélanger, Global Health Law: An Introduction (Cambridge Scientific Pub, Cambridge 2011).
} 
challenge lies in analysing and explaining how they can offer adequate protection in an era of globalisation, which implies a move away from state-centricity.

\section{The rationale for international health law}

Before discussing the nature and scope of international health law, the raison d'être of this emerging branch of international law needs to be discussed. Public international law is subject to increasing fragmentation due to the proliferation of its norms and judicial bodies. ${ }^{11}$ So why, then, is there a need to advance international health law as a new branch of international law? And why propose that new legal instruments be adopted in the context of this field?

The article asserts that the protection of health reflects a pressing social need that needs to be given a stronger voice at the international level, within the framework of international organisations. As stressed in the introduction, there is an urgent need for counterbalancing such interests as international trade, industry and commerce and the interests of warfare against the protection of the health of individuals and populations worldwide. To give three concrete examples:

- the rights of patients to affordable medicines are often at tension with the recognition of excessive intellectual property rights (i.e. patents) of the pharmaceutical industry; ${ }^{12}$

- governmental measures to curb smoking are often counteracted by international trade in tobacco products and excessive advertising for tobacco products;

- health workers in armed conflicts are frequently confronted with a disrespect of international humanitarian rules, which hampers them in the exercise of their duties.

International law and health-related international standard-setting instruments have the potential to play an important role in advancing these and other health-related concerns. Beitz describes human rights as norms that reflect 'urgent individual interests'. For an interest to be 'urgent', its protection must be sufficiently important. Moreover, a

\footnotetext{
${ }^{11}$ On the issue of fragmentation, see, among other papers in the issue, Gerhard Hafner, Pros and Cons Ensuing from Fragmentation of International Law, 25 Mich J Intl L (2003-2004) 845.

12 Prabhakar Singh, No roses without Thorns: global consumers of cut flowers as political actors, 6 Kentucky J Equine, Agriculture \& Natural Resources L (2013-2014) 23-57, 25.
} 
failure to protect this interest would be a matter of international concern. ${ }^{13}$ The article argues that 'health', or 'good health', could be identified as an urgent individual interest, the protection of which is important for individuals, while the international community is inclined to step in if this protection fails. ${ }^{14}$

This is not to suggest that a guarantee of 'good health' implies that there should be an obligation on the part of the State and other entities to ensure that individuals are completely healthy. In the aftermath of World War II, and probably in a state of post-war idealism, the WHO defined 'health' in its Constitution as 'complete physical, mental and social well-being. ${ }^{15}$ As Mason Meier explains, with this definition the WHO expanded its mandate far beyond the traditional focus on the 'absence of disease' so as to also include public health issues more generally. ${ }^{16}$ While this definition has been lauded for its focus on not only the 'physical', but also on 'mental' and 'social' well-being, it has also been criticised for being too broad and absolute in nature. ${ }^{17}$

More contemporary approaches towards defining health can be associated with the so-called "capability approach", as developed by Amartya Sen, Martha Nussbaum and, specifically for health, by Sridhar Venkatapuram. ${ }^{18}$ According to Venkatapuram, the capabilities approach is an 'analytical and ethical framework which asserts that societies should focus on supporting ... the capabilities of individuals to conceive, pursue, and revise their life plans. ${ }^{19}$ The "capability to be healthy" approach, which Venkatapuram proposes, recognises every human being's moral entitlement to a capability to be healthy. ${ }^{20}$ Along similar lines, others argue that the WHO's definition of health is

\footnotetext{
${ }^{13}$ Charles C Beitz, The Idea of Human Rights (OUP, Oxford, 2009) 137.

14 Toebes, Introduction, in, Brigit Toebes et al, Health and Human Rights in Europe,(Intersentia, Antwerp, 2012), 13, 15-16.

15 Preamble to the Constitution of the World Health Organization, 22 July 1946 (entry into force 7 April 1948).

16 Benjamin M Meier, The World Health Organization, The Evolution of Human Rights, and the Failure to Achieve Health for All, in, John Harrington \& Maria Stuttaford (eds) Global Health and Human Rights Legal and Philosophical Perspectives (Routledge, Abingdon, 2010) 163-183 [166].

17 For example, see the discussion at the website of the Dutch organization ZonMw <http://www. zonmw.nl/nl/over-zonmw/begrip-gezondheid/> accessed November 2015.

18 Amartya Sen, Development as Freedom (OUP, Oxford, 1999); Martha Nussbaum, Creating Capabilities: The Human Development Approach (Harvard University Press, Cambridge, 2011); Sridhar Venkatapuram, Health Justice: An Argument for the Capabilities Approach (Polity Press, Cambridge/ Malden, 2011).

19 Venkatapuram, Ibid, 113-115.

20 Ibid.
} 
increasingly problematic; it would contribute to the medicalisation of society and the definition is counterproductive. ${ }^{21}$ They propose a dynamic definition based more on the resilience or capacity to cope and maintain one's integrity, equilibrium and sense of well-being. According to Huber and others, the definition should be 'the ability to adopt and self-manage'. ${ }^{22}$

All in all, health is a vital need that requires strong protection under international law. For international health law, it would be important to focus on the individual's capacity to function adequately in society and to pursue one's life plans. Moving away from the absolute WHO definition prevents persons with chronic diseases or disabilities from being labeled as 'unhealthy'. It also implies that emphasis needs to be placed not only on ensuring access to healthcare services, but also on creating conditions for being healthy, including access to safe drinking water and sanitation, health-related information and education, safe and healthy working conditions, and healthy living environments. The human rights norm that is most closely connected to the protection of health is the right to the highest attainable standard of health, in short, the 'right to health'. As will be discussed more elaborately below, the right to health is a core human rights norm in the field of international health law as it places the emphasis on the protection of individual health worldwide. It emphasizes the need to strive for equity in health.

\section{The sources of international health law}

\subsection{A bird's-eye view of the sources}

International health law brings together international standard-setting instruments adopted in the context of the WHO and under human rights law, while health-related legal rules, norms and other (nonbinding) standards can also be found in several other branches of international law, including under international humanitarian and environmental laws, in medical ethics and patients' rights (see also Fig. 1). In addition, some instruments have an indirect bearing on health, such as the Trade Related Intellectual Property Rights (the

\footnotetext{
${ }^{21}$ Machteld Huber et al, How Should We Define Health, 343 BMJ (2011) d4163.

22 Ibid.
} 


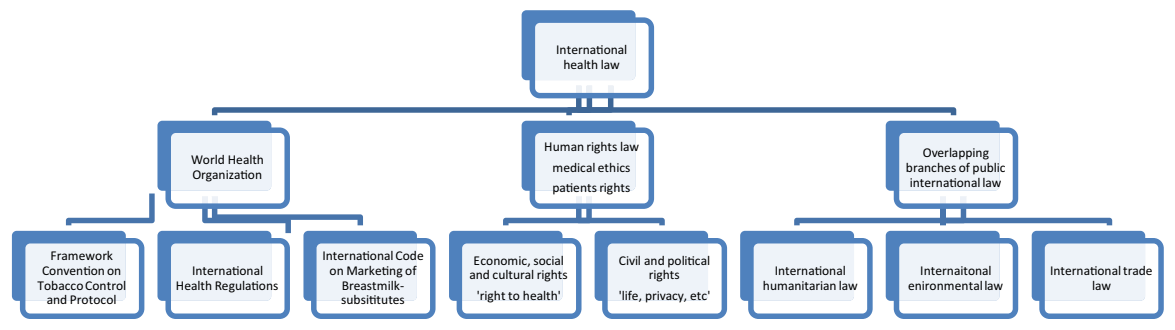

Fig. 1 An overview of the legal instruments and legal norms under international health law

TRIPS) Agreement of the World Trade Organization (the WTO). ${ }^{23}$ For a proper understanding of this emerging field we need to take into account the findings from other related fields in an integrated fashion (section 2 and Fig. 1). ${ }^{24}$

\subsection{The WHO's legal instrumentarium}

Some attention ought to be paid to the standard-setting instruments adopted within the framework of the WHO as it is the main global intergovernmental health body. In fact, the possibilities for the WHO to adopt such instruments are considerable. The Constitution of the WHO provides for the adoption of three different types of instruments: conventions, regulations and recommendations to be found in Articles 19, 21 and 23, respectively. ${ }^{25}$ However, as will be illustrated below, despite these impressive normative powers the WHO possesses, so far, only a limited use of its standard-setting capacity has been made. As Aginam explains, the work of the WHO has for most of its existence been dominated by medical and public health experts, which saw little importance in adopting standardsetting instruments. ${ }^{26}$

Based on Article 19 of the Constitution, the World Health Assembly (the WHA) can adopt conventions and agreements falling

${ }^{23}$ In Novartis AG v Union of India, MANU/SC/0281/2013 [65], the Indian Supreme Court said that the 'Doha Declaration effectively reflected and addressed the deep disquiet of the developing and the leastdeveloped countries regarding their obligation under TRIPS to grant patent protection for pharmaceutical ... products and the likelihood of its highly adverse consequence on public-health.'

${ }^{24}$ See also Allyn Taylor, Governing the Globalization of Public Health, 32(3) J Law, Medicine \& Ethics (2004) 500-508.

${ }^{25}$ See also Obijiofor Aginam, Mission (Im)possible, The WHO as a 'Norm Entrepreneur' in Global Health Governance, in Michael Freeman, Sarah Hawkes \& Belinda Bennett, eds, Law and Global Health: Current Legal Issues Volume 16 (OUP, Oxford, 2014) 560-573. See also Gostin, supra note 10, 110, 116.

26 Aginam, Ibid, 562. 
within the competence of the organisation. For such instruments to be adopted, a two-thirds vote of the WHA is required. So far, the WHO has only adopted one convention based on this provision, i.e. the FCTC, adopted by the WHA on 21 May 2003, and entered into force on 27 February $2005 .{ }^{27}$ It was developed in response to the globalisation of the tobacco epidemic. As would be expected, the tobacco industry was opposed to the adoption of a treaty, and rather favoured voluntary agreements and regulation by the market. $^{28}$ The FCTC contains price and tax measures to reduce the demand for tobacco. It also has non-price measures, including protection from exposure to tobacco smoke, regulation of the contents of tobacco products, as well as packaging and labelling. As will be discussed below, the FCTC has been applied in several tobacco-related cases at the domestic level. On 12 November 2012, the Parties to the FCTC adopted the Protocol to Eliminate Illicit Trade in Tobacco Products in Seoul, the first protocol to the FCTC. $^{29}$

Article 21 of the WHO Constitution enables the WHA to adopt legally binding regulations concerning, inter alia, sanitary and quarantine requirements, the safety, purity and potency of biological and pharmaceutical products, and the advertising and labelling of biological and pharmaceutical products. For the adoption of these binding regulations, the consent from Member States is not required. ${ }^{30}$ The only sets of regulations that have been adopted in this context, so far, are the so-called 'Nomenclature Regulations' ${ }^{31}$ and the 'International Health Regulations' (IHR). The latter were adopted in 1969 as a follow-up to the International Sanitary Regulations adopted by the Fourth WHA in 1951, which again date back to a series of European sanitary conferences held in the $19^{\text {th }}$ Century. ${ }^{32}$ A revised set of IHRs was adopted by the

\footnotetext{
27 For the text of the Convention, see <http://whqlibdoc.who.int/publications/2003/9241591013.pdf > accessed January 2015. See also, Ruth Roemer, Allyn Taylor \& Jean Lariviere, Origins of the Framework Convention on Tobacco Control, 95(6) American J Pub Health (2005) 936-938.

${ }^{28}$ Roemeret al, Ibid, 237.

${ }^{29}$ For the text of the Protocol, see <http:/ / apps.who.int/iris/ bitstream/10665/80873/1/9789241505246_ eng.pdf $>$ accessed November 2015. As at November 2015, the Protocol has 54 signatories and only 11 ratifications. For an evaluation, see Jonathan Liberman, 16(31) ASIL Insight <https://www.asil.org/insights/ volume/16/issue/38/new-who-fctc-protocol-eliminate-illicit-trade-tobacco-products $>$ accessed November 2015.

30 See the 'contracting out' procedure in Article 22.

31 WHO, World Health Organization Regulations No. 1 regarding Nomenclature (including the Compilation and Publication of Statistics) with respect to Diseases and Causes of Death, adopted on 24 July 1948 and amended in 1956 and 1967.

32 Gostin, supra note 10, 111.
} 
WHO in $2005 .{ }^{33}$ Contrary to the previous Regulations, these new regulations no longer limit their application to specific diseases. ${ }^{34}$ They are essentially aimed at outlining the roles and obligations of the WHO member states when addressing public health emergencies of international concern. ${ }^{35}$ The document contains some cross-connections with human rights law. ${ }^{36}$ For example, Article 3(1) of the Regulations states that their implementation 'shall be with full respect for the dignity, human rights and fundamental freedoms of persons', thereby underscoring the importance of human rights protection during public health emergencies.

Article 23 of the WHO Constitution enables the WHA to 'make recommendations to Members' and Article 62 requires States to report annually on the action taken to comply with recommendations. The WHO's most authoritative recommendations are the International Code of Marketing of Breast-Milk Substitutes (1981) and the Global Code of Practice on the Recruitment of Health Personnel (2010). ${ }^{37}$ Despite its non-binding nature, the Breast-Milk Code is an authoritative document that has led 84 countries to adopt domestic legislation implementing the Code. ${ }^{38}$ On the other hand, as asserted by Gostin, the Global Code of Practice on the International Recruitment of Health Personnel has not been as authoritative and has had little impact on domestic laws, policies and practices. ${ }^{39}$ In addition to the recommendations adopted under Article 23 of the WHO Constitution, the WHO has the habit of adopting recommendations outside Article 23. Examples include the WHO's recommendations on nutrition, on infant feeding and on physical activity for health. ${ }^{40}$

\footnotetext{
${ }^{33}$ WHO, Fifty-Eight World Health Assembly, Revision of the International Health Regulations, W.H.A. Doc. 58.3 (May 23, 2005). Entry into force 15 June 2007 <http://www.who.int/ihr/9789241596664/en/ index.html> accessed November 2015.

34 Article 2 of the International Health Regulations and its Preamble.

35 International Health Regulations, see also Eric Mack, The World Health Organization's New International Health regulations: Incursion on State Sovereignty and Ill-Fated Response to Global Health Issues, 7 Chi J Intl L (2006-2007) 365-377, 369.

${ }^{36}$ For an elaborate analysis of these cross-connections, see Andraž Zidar, WHO International Health Regulations and Human Rights: From Allusions to Inclusion, 19(4) Intl J Human Rights (2015) 505-526.

37 WHO, International Code of Marketing of Breast-Milk Substitutes (1981) <http://www.who.int/ nutrition/publications/code_english.pdf $>$ accessed November 2015; Global Code of Practice on the Recruitment of Health Personnel (2010) <http://www.who.int/hrh/migration/code/WHO_global_code_ of_practice_EN.pdf $>$ accessed October 2015 .

38 Gostin, supra note 10, 105.

39 Ibid, 67.

${ }^{40}$ Generally, see <www.who.int> accessed November 2015.
} 
In addition to standard-setting instruments, the WHO has launched a range of international campaigns and it has adopted a considerable number of global strategies. In 1978, the WHO adopted its landmark Alma-Ata Declaration on Primary Health Care, which set the target of providing primary healthcare for all by the year $2000 .^{41}$ While the programme was criticised for inadequate implementation during the 1980 s and 1990s, the WHO revitalised it in $2008 .^{42}$ It is also interesting to see that General Comment number 14 on the right to the highest attainable standard of health integrates language from the Alma-Ata Declaration by using the definition of 'primary healthcare' for the identification of legal 'minimum core obligations' under the right to health. ${ }^{43}$

\subsection{Human rights law}

International human rights law also plays an important role in international health law. Given that international health law is aimed at the protection of health, the most important human rights norm is the 'right to the highest attainable standard of health', in short, the 'right to health'. Arguably, the right to health features as a core standard in the field of international health law, as it places the emphasis on the protection of individual health worldwide, and because it emphasises the need to strive for equity in health.

The WHO was the first organisation to lay down a right to health. The preamble to the Constitution of the WHO both defines 'health' and recognises health as a right. ${ }^{44}$ In connection with the right to health, the Preamble refers to the relation between health problems and unequal development in different countries, to the importance of the healthy development of the child, and to the importance of the informed opinion and active co-operation on the part of the public: notions that still bear relevance today. The adoption of the right to health by the WHO was a breakthrough in the field of international

\footnotetext{
${ }^{41}$ WHO, Declaration of Alma-Ata, Primary Health Care, Report of the International Conference on Primary Health Care, Alma-Ata, USSR, 6-12 September 1978, 'Health for All' Series No 1, WHO, Geneva/New York, 1978.

42 WHO, Return to Alma-Ata, 2008 <http://www.who.int/dg/20080915/en/> accessed November 2015.

43 Interpreting Article 12 of the UN International Covenant on Economic, Social and Cultural Rights (ICESCR). General Comment 14 [43-44].

${ }^{44}$ Preamble to the Constitution of the World Health Organization, adopted 22 July 1946 (entry into force 7 April 1948).
} 
health and human rights law and it created an important point of departure for the further elaboration of a right to health in human rights documents.

The 'right to health' in the Constitution of the WHO has inspired the right to health provisions that were drafted at a later stage, in particular Article 12 of the UN International Covenant on Economic, Social and Cultural Rights (the ICESCR). ${ }^{45}$ Article 12 of the ICESCR contains a provision along the lines of the the WHO Constitution. ${ }^{46}$ It recognises the 'right to the highest attainable standard of health' and mentions four concrete undertakings for States to realise this goal. In 2000, the Committee on Economic, Social and Cultural Rights (the CESCR) adopted General Comment 14, an explanatory document to the right to health in Article 12 of the ICESCR. ${ }^{47}$ While this document is not legally binding and can thus be characterised as a 'soft law' instrument, it is considered authoritative by many scholars and practitioners from the field. ${ }^{48}$ It mentions a range of important signposts for the right to health which are frequently mentioned and applied by human rights scholars, NGOs, and increasingly also by judicial bodies and State authorities. $^{49}$

\footnotetext{
${ }^{45}$ Other right to health provisions can be found, inter alia, in Article 12 of the Convention on the Elimination of all forms of Discrimination against Women (CEDAW, 1979) and Article 24 of the Convention of the Rights of the Child (CRC, 1989). While 12 CEDAW focuses primarily on access to healthcare for women, Article 24 CRC covers the broader right to health of children, in referring not only to healthcare facilities, but also to adequate food, drinking water and prohibition of harmful traditional practices. In addition to the above-mentioned provisions, a number of other UN treaties and declarations exist that refer to a right to health. In addition, the Convention on the Protection of the Rights of All Migrant Workers and Members of their Families (MWC, 1990) places emphasis on equal access to medical care for migrant workers. Article 5(e)(iv) of the Convention on the Elimination of All Forms of Racial Discrimination (CERD, $1965)$ is slightly more elaborate, in that it provides in general terms that States Parties are to prohibit and eliminate racial discrimination in the enjoyment of public health, medical care, social security and social services. Also worth mentioning are Rules 22 to 26 of the Standard Minimum Rules for the Treatment of Prisoners (1957), which lay down a number of principles for the treatment of sick prisoners. Finally, the Conventions of the ILO contain numerous references to a specific area of health, namely occupational health. Different in character is Article 25 of ILO Convention No. 169 (1989), which explicitly recognises a right to health of indigenous and tribal peoples. Lastly, worth mentioning is the Convention on the Rights of Persons with Disabilities (CRPD, 2006), which contains several references to the health of disabled persons, including Article 25 on the right to health of disabled persons.

46 Brigit Toebes, The Right to Health as a Human Right in International Law (Intersentia/Hart, Antwerp/ Oxford, 1999) 43.

47 Committee on Economic, Social and Cultural Rights, The Right to the Highest Attainable Standard of Health, UN General Comment No 14 (2000), UN Doc E/C12/200/4 (11 August 2000).

${ }^{48}$ See, for example, the reference to Genera, Comment 14 on the website of the Special Rapporteur on the Right to the Highest Attainable Standard of Health, <http://www.ohchr.org/EN/Issues/Health/ Pages/SRRightHealthIndex.asp $>$ accessed November 2015. See also Paul Hunt, Health and Human Rights Project <https://www.essex.ac.uk/hrc/practice/health-and-human-rights.aspx > accessed November 2015.

49 See also Helen Potts, Accountability and the Right to the Highest Attainable Standard of Health, University of Essex Human Rights Centre/Open Society Institute <http://repository.essex.ac.uk/9717/1/ accountability-right-highest-attainable-standard-health.pdf $>$ accessed November 2015.
} 
Firstly, General Comment 14 recognises that the right to health is not a right to be healthy, but rather a broad human right extending not only to access to healthcare services but also to the underlying determinants of health, including an access to safe and potable water and adequate sanitation, healthy occupational and environmental conditions, and access to health-related education and information. ${ }^{50}$

As such, the right to health has two dimensions: a right to healthcare services and a right to a broad set of underlying conditions for health. So it has many cross-connections with the other existing human rights (indirectly) aimed at protecting health, including the rights to education, water and sanitation, and housing. A further important component of General Comment 14 concerns the identification of a set of guiding principles that apply with respect to all health-related services: States are to guarantee the availability, accessibility, acceptability and quality of health facilities (the so-called 'AAAQ'). ${ }^{51}$

Accessibility has four overlapping dimensions: non-discrimination, physical accessibility, economic accessibility (affordability) and information accessibility. ${ }^{52}$ Furthermore, General Comment 14 defines a set of legal state obligations to 'respect, protect and fulfil' human rights and also describes potential violations of states in relation to a right to health. ${ }^{53}$ Lastly, an important component of the General Comment is the definition of a set of legal core obligations resulting from the right to health, minimum essential levels of health services which States have to guarantee 'at the very least'. ${ }^{54}$ As mentioned above, the minimum core obligations were partly inspired by the WHO's Primary Health Care Strategy. ${ }^{55}$ This 'minimum core' may provide inspiration for the identification of minimum obligations in specific settings such as humanitarian and man-made emergencies or periods of financial crisis.

As was suggested above, the right to health could feature as a key standard in international health law, thus reflecting the need to protect and promote the health of the world's population. When it comes to applying the right to health in this way, a word of caution is also appropriate. The right to health has rightly been criticised for being

\footnotetext{
${ }^{50}$ General Comment 14 supra note $47[8,11]$.

51 Ibid [12].

52 Ibid, [12].

53 Ibid, [33-37].

54 Ibid, [43-44].

55 WHO, Declaration of Alma-Ata, 6-12 September 1978. <http://www.who.int/publications/almaata_ declaration_en.pdf> accessed December 2015.
} 
imprecise, only progressively realisable and often unenforceable..$^{56}$ There is, thus, an urgent need to study the potentials and limitations of the right to health in this context.

A specific concern is that, in the field of international health law, the right to health would primarily be used as a 'collective' norm, protecting the health-related interests of a community or the population at large. The right to health is then understood as a norm that reflects the protection of 'public health'. It is somewhat problematic to perceive the right to health as a norm that pertains to collective claims; firstly, because as a human right the right to health pertains to an individual rather than to a collective claim. ${ }^{57}$ This does not mean that our existing individual rights cannot lead to collective claims, however. We could perceive the right as materially conferred on individual members of a group, but procedurally looked after by the collectivity. Hence this could potentially be overcome by perceiving the collective right to health as a bundle of individual rights. ${ }^{58}$ An example of a legal mechanism where the right to health and other economic and social rights are exercised in this way is the collective complaints procedure under the (Revised) European Social Charter, which is monitored by the European Committee on Social Rights. ${ }^{59}$

Another concern in the collective exercise of the right to health is that there can be a tension between this presumed public health component of the right to health and the civil and political rights of individuals, including their rights to security, liberty, physical integrity, privacy and family life, but potentially also their individual right to the best possible healthcare. To give one example: in the 2014 Ebola crisis, measures had to be taken for the protection of 'public health'. However, at the same time, the rights of individual patients and others involved in the crisis had to be respected and protected. ${ }^{60}$ This tension shows that if the right to health is to be employed as a core standard in international health law, more research should go into understanding how it can be applied in a sensible way without undermining the rights of individuals.

\footnotetext{
56 Gostin, supra note 10, xv.

57 Brigit Toebes, Human Rights and Public Health: Towards a Balanced Relationship, 19(4) Intl J Human Rights (2015) 488-504. Also, <http://www.who.int/publications/almaata_declaration_en.pdf > accessed December 2015.

58 Marlies Galenkamp, Collective Rights, in, SIM Special No 16 (Netherlands Institute of Human Rights, Utrecht, 1995) 53-102, 70-71. See, Toebes, Ibid, 55.

59 European Committee of Social Rights (Council of Europe), Collective Complaints Procedure <http:// www.coe.int/t/dghl/monitoring/socialcharter/Complaints/Complaints_en.asp> accessed October 2015.

${ }^{60}$ Toebes, supra note 57; Zidar, supra note 36.
} 
In addition to the 'right to health', many other human rights are, in one way or another, connected to health, including the right to life, the prohibition of torture as well as the rights to information and education. ${ }^{61}$ Increasingly, therefore, reference is made to 'health and human rights' as a distinct field of human rights law, so as to refer to the many intersections between health and the various relevant human rights standards. ${ }^{62}$ Important concerns that are addressed from this perspective include the position of vulnerable persons in healthcare settings, reproductive health issues, medical-ethical issues such as abortion and euthanasia, and the health protection of vulnerable groups such as women, children and the elderly. The emerging human rights field of 'health and human rights' plays an important role in international health law.

\section{The scope of international health law: three important dimensions}

\subsection{Health security threats}

Traditionally, a key topic of public international law concerned the protection against health security threats. The scope of 'health security' has expanded gradually over the course of the previous decennia. While legal efforts to protect against health security threats were initially focused primarily on limiting the spread of infectious diseases, ${ }^{63}$ increasingly other health security threats are addressed as well, including the detrimental health effects of armed conflict and, in relation to this, the need to protect against the use of biological, chemical and nuclear weapons. ${ }^{64}$ While environmental health considerations are potentially also issues of 'health security', they are left outside the scope of this section.

\footnotetext{
${ }^{61}$ The so-called 'International Bill of Human Rights' embraces the Universal Declaration of Human Rights (UDHR, 1948), the International Covenant on Civil and Political Rights (ICCPR, 1966) and the International Covenant on Economic, Social and Cultural Rights (ICESCR, 1966). The UDHR, which contains both civil and political rights and economic, social and cultural rights, recognises a right to an adequate standard of living (Article 25), which includes a right to medical care and necessary social services. While the ICCPR contains a number of health-related civil and political human rights, including the right to life and the prohibition of torture, the ICESCR recognises in Article 12 the right to the highest attainable standard of health'. Subsequently, a number of UN human rights treaties were gradually adopted that integrate civil and political rights and economic, social and cultural rights.

62 Toebes et al, supra note 14, in particular Chapter 3.

63 Sophie Harman, Global Health Governance: No 60 (Routledge Global Institutions Series, Abingdon, 2012) 19-23.

${ }^{64}$ Harman, supra note 63, 21, referring to David Fidler \& Lawrence Gostin, Biosecurity in the Global Age: Biological Weapons, Public Health and the Rule of Law (Stanford Univ Press, Stanford, 2008).
} 
The protection against the spread of infectious diseases traditionally forms part of the health-related tasks of national governments. This duty is also formulated under international human rights law: e.g. the right to health in Article 12 ICESCR formulates the duty of States to take measures for the prevention, treatment and control of epidemic, endemic, occupational and other diseases' ${ }^{65}$

Due to increasing globalisation of infectious diseases, there has been an ongoing and growing need for international coordination in this field. As mentioned above, in 2005 the WHO adopted a new set of International Health Regulations which are aimed at offering protection against a wide range of public health threats. ${ }^{66}$ The recent Ebola crisis has been an important test case for assessing the effectiveness of the new Regulations. While the domestic health systems in the affected countries failed to address the crisis appropriately, a major international response was not put into place. ${ }^{67}$ As will be discussed further below, the WHO lacks the coordinating and financial capacities for dealing adequately with public health emergencies of such a large and complex scale.

For international health law, it is also important to assess the interplay between the Regulations and human rights norms, in particular those pertaining to individual patients and others who may potentially carry on the disease. During health emergencies, the rights of individual patients and others are easily overlooked. While the Regulations seem to incorporate human rights law, the precise implications of this interface at a practical level demand further study. ${ }^{68}$

Furthermore, as mentioned, there is a need to address the connections between health and armed conflict under international health law. It has been stressed on various occasions that war and health influence each other mutually: while health is seen as a preventer of war, war and violent conflict can have a devastating effect on the lives

\footnotetext{
${ }^{65}$ E.g. Jos Dute, De bestrijding van infectieziekten in een veellagige rechtsorde [Combating infectious diseases in a multi-layered legal order], in, AC Hendriks \& H-MThD Ten Napel (eds) Volksgezondheid in een veellagige rechtsorde, Eenheid en verscheidenheid van norm en praktijk (Kluwer, Alphen aan den Rijn, 2007) 123-136 (emphasis added).

${ }^{66}$ The WHO, Fifty-Eight World Health Assembly, Revision of the International Health Regulations, W.H.A. Doc. 58.3 (May 23, 2005) (Entry into force 15 June 2007) <http://www.who.int/ihr/ 9789241596664/en/index.html> accessed November 2015.

${ }^{67}$ See this author's blog post The ebola crisis: challenges for global health law (posted 3 February 2015) $<$ https:// ghlgblog.wordpress.com/2015/02/03/the-ebola-crisis-challenges-for-global-health-law/ > accessed November 2015.

${ }^{68}$ For a thorough analysis, see Zidar, supra note 36.
} 
and health of both combatants and civilians. ${ }^{69}$ This means, on the one hand, that by enhancing good health among a population, conflicts could potentially be prevented, hence the need to enhance the health of individuals.

By preventing armed conflicts, health and well-being could be spared. Article 55 of Additional Protocol I (applicable during international armed conflicts) focuses on the protection of the natural environment: 'Care are shall be taken in warfare to protect the natural environment against widespread, long-term and severe damage. This protection includes a prohibition of the use of methods or means of warfare which are intended or may be expected to cause such damage to the natural environment and thereby to prejudice the health or survival of the population. ${ }^{, 70}$

The notion that weapons can cause severe damage to health is also underlying the weapons' Conventions, including the Chemical Weapons Convention and the Biological Weapons Convention. ${ }^{71} \mathrm{~A}$ specific dimension of the connection between health and armed conflicts is that, during armed conflicts, health workers, their hospitals and equipment increasingly become the object of an attack. The ICRC study titled 'Healthcare in danger' reports that, around the world, people who risk their lives to provide healthcare in conflict areas are under increasing threat. ${ }^{72}$ Potentially, the intertwined fields of human rights law, humanitarian law and medical ethics provide a compelling normative framework for the protection of healthcare provision and the safeguarding of medical neutrality in armed conflicts and other emergency situations. ${ }^{73}$

\subsection{Access to healthcare services and the underlying determinants to health}

Securing access to access to healthcare services is a key component of the internationally recognised 'right to health'. Based on the international

\footnotetext{
${ }^{69}$ Harman, 2012, 20, referring to Joanna Santa Barbara \& Graeme MacQueen, Peace through Health: Key Concepts, 364 Lancet (2004) 384-386.

70 Article 55 Additional Protocol I to the Geneva Conventions, adopted 8 June 1977.

71 Biological Weapons Convention, opened for signature on 10 April 1972; Convention on the Prohibition of the Development, Production, Stockpiling and Use of Chemical Weapons and on their Destruction, adopted 30 November 1992; Biological Weapons Convention, opened for signature on 10 April 1972.

72 ICRC, Healthcare in Danger <http://www.redcross.int/EN/mag/magazine2011_2/4-9.html> accessed November 2015.

73 Brigit Toebes, Health and Humanitarian Assistance: Towards an Integrated Norm under International Law, 18 Tilburg L Rev (2013) 133-151.
} 
human right to health, States are required to realise the right to healthcare domestically. Important yardsticks for this realisation are the abovementioned 'AAAQ', requiring that healthcare services are available, accessible, acceptable and of good quality for everyone residing on their territory. ${ }^{74}$ Complex questions arise as to which services should be provided, and where to draw the line, for example, when it comes to more specialized care, healthcare facilities in remote areas and persons not carrying health insurance. While the health problems and needs in developed and developing countries differ to a great extent, at a more abstract level very similar questions arise, for example, on how to allocate the (limited) budgets in a fair and efficient manner, taking into account the needs of the various population groups, as well as individual needs.

Some of these questions have transnational dimensions, for example, when it comes to the affordability of medicines in the developing world and the increasing expansion of cross-border healthcare delivery and financing. ${ }^{75}$ This raises the question of which actors have obligations to realise the right to health. While the State bears the primary responsibility for realising the right to health, developed States and international organisations may carry responsibilities to realise the right to health in developing nations. ${ }^{76}$ Furthermore, the pharmaceutical industry, health insurance companies and healthcare providers, in light of the power and influence they exercise over the health and well-being of individuals, may also be considered to carry responsibilities under the right to health.

As suggested above, the rights of patients also form a component of international health law. In human rights law, patients' rights are increasingly recognised and addressed. As a result, the field of patients' rights is becoming a well-established branch of human rights law with its own characteristics. ${ }^{77}$ Patients' rights focus specifically on the relationship between the healthcare provider and his or her patient. This relationship is quite often characterised by an imbalance of power as, generally speaking, the healthcare provider has information and skills which the patient lacks. Moreover, the healthcare provider has the

\footnotetext{
74 General Comment 14, supra note 47 [12].

75 Directive 2011/24 of the European Parliament and of the Council on the Application of Patients' Rights in Cross-Border Healthcare, OJ 2011 L 88/45. For a critical comment, see BMJ Editorial 203/347, published 31 December 2013 <http://www.bmj.com/content/347/bmj.f7694>. See also Janne Rothmar Herrmann and Brigit Toebes, The European Union and Health and Human Rights, in Toebes et al, supra note $14,51-78$, in particular pp. 66-67.

76 For this, a basis is often sought in Article 2(1) ICESCR.

77 See also Mette Hartlev, Patients' Rights, in Toebes et al, supra note 14, 111-144.
} 
privilege to touch and invade the body of the patient, thus placing the patient in a vulnerable position. ${ }^{78}$ From a European legal human rights perspective, the European Court of Human Rights (the ECtHR) plays an important role in clarifying how human rights apply in healthcare settings. ${ }^{79}$ More generally, the prohibition of torture and inhuman and degrading treatment, as set forth in several international human rights standards, is increasingly used as a standard of protection in healthcare settings. ${ }^{80}$ As the Open Society Foundations explain:

$[A]$ cross the world, health systems often serve as venues of punishment, coercion, and violations of basic human rights, sometimes amounting to torture or cruel, inhuman, and degrading treatment. This abuse is especially prevalent in the care of socially marginalized groups-people living with HIV, ethnic minorities, sexual and gender minorities, people who use drugs, and people with intellectual disabilities or mental health problems. ${ }^{81}$

In addition to healthcare, international health law should also engage with securing the underlying determinants to health, including such issues as access to safe drinking water and sanitation, health-related information, environmental and occupational health. It is widely acknowledged that the causes of ill-health and health inequalities go far beyond the possibility to access healthcare services. In the wellknown 'Whitehall study', conducted in the United Kingdom in the 1960s, civil service clerks were four times more likely to die young than civil servants with higher positions but with the same access to healthcare services. ${ }^{82}$ Public health experts use the term 'social determinants of health', which are meant to include our general living environment and the structures of society at large as decisive conditions to our health.

In 2008, the WHO's Committee on the Social Determinants of Health (the CSDH) published a crucial report, in which it established

\footnotetext{
${ }^{78}$ Elizabeth Wicks, Human Rights and Healthcare (Hart, Oxford and Portland, 2007), referring to I Kennedy, Treat Me Right: Essays in Medical Law and Ethics (Clarendon Press, Oxford, 1991) 387.

79 See also Aart Hendriks, The Council of Europe and Health and Human Rights, in Toebes et al, supra note $14,23-50$.

${ }^{80}$ Open Society Foundations, Twenty Mechanisms for Addressing Torture in Healthcare, June $2012<$ http:// www.opensocietyfoundations.org/publications/twenty-mechanisms-addressing-torture-health-care $>$ accessed January 2015. See also Veelke Derckx, Antenor Hallo de Wolf \& Brigit Toebes, Implementing the Torture Convention: protecting human dignity and integrity in healthcare, report (in Dutch and English) August 2013 $<$ http:/ / www.rug.nl/research/groningen-centre-for-law-and-governance/programmas/public-trust-andpublic-law/osi-project/opcat-implementation-in-health-care-settings-in-the-netherlands?lang=en $>$ accessed November 2015.

81 Open Society Foundations (OSF) 2012.

82 As quoted in, inter alia, Michael Marmot, The Status Syndrome: How Social Standing Affects Our Health and Longevity (Henry Holt and Company, New York, 2004) 38-39.
} 
that health inequities arise because of the unequal distribution of power, income, goods and services and because of the circumstances in which people live, including their access to healthcare, education, their conditions of work and leisure, their homes and communities. ${ }^{83}$ The $\mathrm{CSDH}$ makes a clear appeal to the international human rights community by concluding that 'Putting right these inequities - the huge and remedial differences in health between and within countries is a matter of social justice. Reducing health inequities is ... an ethical imperative. Social injustice is killing people on a grand scale.' ${ }^{84}$

Important challenges lie in exploring how the social determinants of health can be addressed from the perspective of human rights and international law more generally. Part of the solution may lie in connecting the different human rights together. Knowing that the ways we are raised, educated and work are decisive to our health implies looking into how the right to health is connected to other health-related rights, including the rights to education, housing and work, which reflect values like good quality education and adequate labour standards. This approach is very much in keeping with the notion of the 'indivisibility, interdependence and interrelatedness' of all human rights, as was affirmed in the Vienna Declaration and Programme of Action, adopted in $1993 .{ }^{85}$

A related challenge for international health law concerns the dramatic global increase of chronic or non-communicable diseases (the NCDs) such as cancer, diabetes, respiratory diseases and cardiovascular conditions. The NCDs accounted for 65 per cent of global death in 2010 and are set to rise by 17 per cent over the next decade. ${ }^{86}$ Noncommunicable diseases are set to increase disproportionately in low and middle-income countries over the next 20 years, which is expected to enhance poverty and to reduce economic growth. ${ }^{87}$ As chronic diseases are quite often lifestyle-related, the question arises if, and if so how,

\footnotetext{
${ }^{83}$ The WHO, Commission on the Social Determinants of Health (CSDH), Closing the gap in a generation: health equity through action on the social determinants of health. Final Report of the Commission on Social Determinants of Health, 2008 <http://www.who.int/social_determinants/thecommission/finalreport/en/ index.html >. Accessed November 2015.

84 Ibid, 10.

85 Vienna Declaration and Programme of Action, UN Doc A/Conf.157/23 (12 July 1993) [5]. See also M. Marmot et al, WHO European Review of Social Determinants of Health and the Health Divide, The Lancet, 380 (2012) 1011-29.

${ }^{86}$ Gostin, 2014, referring to Rafael Lozano et al, Global and Regional Mortality from 235 Causes of Death for Twenty Age Groups in 1990 and 2010: A Systematic Analysis for the Global Burden of Disease Study 2010, 380 The Lancet (2012) 2095-2128.

87 Consumers International and World Obesity Forum, 2014.
} 
governments should attempt to influence the consumption patterns of consumers or, in other words, whether they should 'nudge' their population towards healthier behaviour. ${ }^{88}$

At the domestic level, governments increasingly attempt to regulate certain aspects of food and beverages, such as the advertisement, packaging, size, and salt, sugar and (trans) fat content. ${ }^{89}$ Potentially also, governments have responsibilities under the right to food and the right to health to regulate the food and beverage industries. In addition, the food and beverage producers themselves, although strictly speaking not legally bound by the human rights treaties, potentially have indirect responsibilities under human rights law to ensure the healthiness of their products. ${ }^{90}$ From the perspective of international health law, the possibilities for adopting an international instrument addressing these matters could be considered. ${ }^{91}$

\subsection{Health and international trade}

As was already pointed out above, there are many connections between the international trade law framework and the international healthrelated standards, often leading to a tension between the urge to foster international trade and the need to protect the health of the public. ${ }^{92}$ While it goes beyond the scope of this article to give a comprehensive overview of all these dimensions, three important tensions are discussed here.

Firstly, the WTO law gives Members the possibility to adopt measures for the protection of public health. The General

\footnotetext{
${ }^{88}$ Cass R Sunstein, Why Nudge - The Politics of Libertarian Paternalism (Yale Univ Press, New Haven $\&$ London, 2014).

${ }^{89}$ Allyn A Taylor, Emilio W Parento \& Laura A Schmidt, The Increasing Weight of Regulation: Countries Combat the Global Obesity Pandemic, 90(1) Indiana $L J<$ http://scholarship.law.georgetown. edu/cgi/viewcontent. cgi?article $=2338 \&$ context $=$ facpub $>$ accessed September 2015.For example, the restriction on the sale of large sugary drinks in NY City, New York Times, Health panel approves Restriction on Sale of Large Sugary Drinks, September 13, $2002<\mathrm{http}$ // www.nytimes.com/2012/09/14/nyregion/ health-board-approves-bloombergs-soda-ban.html?smid=tw-share $\&$ rmoc.semityn.www $\&$ _r $=0>$ accessed September 2015.

90 See, for example, Conference Statement Food Corporations and Human Rights, 11-12 September 2014 <http://www.uio.no/english/research/interfaculty-research-areas/leve/news-events/events/2014/globalfood-systems-hr/final-statement-from-oslo-conference-071014.pdf $>$ accessed September 2015.

${ }^{91}$ For an initiative in this regard, see Consumers International and World Obesity Forum, Recommendations Towards a Global Convention to Protect and Promote Healthy Diets, May $2014<w w w$. worldobesity.org $>$. Accessed November 2015. See also Urgently Needed: A Framework Convention for Obesity Control, 387 The Lancet 378 (2011) 741.

92 See in details, Singh, supra note $12,57$.
} 
Agreement on Tariffs and Trade (the GATT), which covers international trade in goods, permits Member States in Article $\mathrm{XX}(\mathrm{b})$ GATT to take measures 'necessary to protect human, animal or plant life or health'. This provision, which creates a tension with the principle of non-discrimination mentioned above, recognises that Members may wish to give priority to public health concerns. ${ }^{93}$ More specific rules for the protection of health have been adopted under the Agreement on Sanitary and Phytosanitary Measures (the SPS). This Agreement regulates 'sanitary measures', which relate to human or animal health, and 'phytosanitary measures', which deal with plant health.

The relationship between this framework and the human rights framework is still under-explored. While members invoking these public health clauses could potentially invoke the right to health, Members barred from trading their goods based on such measures could possibly stress the right to development of their people. It is important to strike a balance between allowing Members to protect public health or other social interests and preventing them from using these policies in such a way that they have a negative effect on trade and on the interests of the other Members. ${ }^{94}$

Secondly, there is potentially a tension between the realisation of the right to healthcare at the domestic level, and the liberalisation and marketization of healthcare services. While privatisation and liberalisation can make the provision of healthcare more efficient, it may also place the affordability and accessibility of healthcare under threat. ${ }^{95}$ More specifically, looking at the WTO framework, the Trade in Services (the GATS) is aimed at the liberalisation of trade in services. This potentially threatens the ability of State to realise the right to healthcare at the domestic level. According to Hilary in a study for Save the Children, the specific provisions of GATS undermine the ability of countries to implement their own public health priorities. ${ }^{96}$ These tensions merit further attention from international health lawyers.

\footnotetext{
93 WTO Agreements \& Public Health, 2002, 11.

94 Simon Lester, Bryan Mercurio \& Arwel Davies, World Trade Law, (2 ${ }^{\text {nd }}$ end Hart Publishing 2012) 364.

95 Brigit Toebes, The Right to Health and the Privatization of Health Care Services: A Case Study of the Netherlands, 9(1) Health \& Human Rights (2006) 102-127.

96 John Hilary, The Wrong Model, GATS, Trade Liberalization and Children's Right to Health, Save the Children 2001. See also André den Exter, GATS en de Zorgverzekeringswet: een controverse?, in, AC Hendriks \& H-MThD Ten Napel (eds), supra note 65, 63-76.
} 
Thirdly, the trade regime can create a tension with the need to ensure access to affordable medicines, especially in the developing world. It is estimated that almost 2 billion people lack access to essential medicines. ${ }^{97}$ The availability and affordability of drugs in developing countries are hampered by the TRIPS Agreement which requires for 20 years' of patent protection of newly developed drugs. This regime has, therefore, been criticized widely for not respecting the right to health. ${ }^{98}$ However, the landmark ruling of the Indian Supreme Court, Novartis AG v Union of India, attempts to balances the trade - particularly intellectual property concerns - with health concerns to offer a blueprint of international health law. Aftab Alam J wrote lucidly to express a juristic concern for patients in lowincome countries balancing, at the same time, India's intellectual property commitments and global welfare concerns:

[The India Supreme Court ... refers ... to the TRIPS] Agreement as being the cause of a good deal of concern not only in this country but also ... in other parts of the world; the concern being that patent protection to pharmaceutical ... products might have the effect of putting life-saving medicines beyond the reach of a very large section of people. [T] he Indian legislature [has] addressed this concern and, while harmonizing the [Indian] patent law ... with the provisions of the TRIPS Agreement, [India has ] strove to balance its obligations under the international treaty and its commitment to protect and promote public health considerations, not only of its own people but in many other parts of the world (particularly in the [d]eveloping ... and the [1]east [d]eveloped [c]ountries). ${ }^{99}$

Such rulings can have a considerable impact on the health-related instruments and norms in international law. After all, judicial decisions are seen sources of international law. ${ }^{100}$ It is remarkable that the Indian Supreme Court, while noting India to be the "pharmacy of the world", cited a number of countries where cheap drugs from India help in fighting cancer. Admirably enough, the Supreme Court's concern was not local but international. ${ }^{101}$

\footnotetext{
97 The WHO, Medicines Strategy: Countries at the Core, 2004-2007 (WHO, Geneva, 2004). See also Paul Hunt \& Rajat Khosla, The Human Right to Medicines, 5(8) Sur: Intl J Human Rights (2008) 99-115.

98 TRIPS Agreement, signed in Marrakesh, Morocco, on 15 April 1994. Inter alia, Paul Hunt, Mission to the World Trade Organization, 2004; Gabriela Costa Chaves, Marcela Fogaça Vieira \& Renata Reis, Access to Medicines and Intellectual Property in Brazil: Reflections and Strategies of Civil Society, 5(8) SUR - Intl J Human Rights (2008) 163-189; Nathan Ford, David Wilson, Onanong Bunjumnong \& Tido von Schoen Angener, The Role of Civil Society in Protecting Public Health over Commercial Interests: Lessons from Thailand, 363 Lancet (2004), 560.

99 Novartis AG v Union of India, MANU/SC/0281/2013 [66].

${ }^{100}$ ICJ Statute Article 38(1)(d) <http://www.icj-cij.org/documents/?p1=4\&p2=2> accessed 28 Jan 2016.

101 Prabhakar Singh, India before and After the Right of Passage case, 5 Asian J Intl L (2015) 176, 203-205.
} 


\section{Towards accountability of responsible actors}

\subsection{Domestic and international accountability}

After this identification of the relevant standard-setting instruments and their potential application in practice, I will now analyse the way in which these instruments are implemented, monitored and enforced by the responsible actors. These questions are closely connected to the notion of governance which could, in this context, be defined as the totality of ways in which a society organises and manages its healthrelated concerns. ${ }^{102}$ In the context of international health law, a distinction can be made between domestic and global health governance, where domestic health governance concerns the totality of efforts at the national level, whereas global health governance refers to the efforts at the international level geared towards protecting and promoting health. To some extent this distinction is artificial, as global and national health laws are very much intertwined; however, it may help us gain a clearer picture of the nature and adequacy of the existing efforts at various levels of governance and accountability.

Ultimately, the aggregate of such efforts should lead to what is also addressed as 'good governance', i.e. ensuring that the efforts geared towards the protection and promotion of health at both international and national levels are transparent, accountable and participatory, taking into account the relevant human rights, humanitarian and ethical standards. ${ }^{103}$ Key components of a good governance process include participation, the rule of law, transparency, responsiveness, equity, effectiveness and efficiency, and accountability. ${ }^{104}$ Human rights law emphasises similar principles, in particular the notions of accountability and participation. However, there is still a lack of understanding as to what it means to create 'accountability' for human rights violations, for example, and of how 'participation' can be enhanced, for example, in the decision-making process over important decisions in the health sector. ${ }^{105}$

\footnotetext{
102 Julio Frenk \& Suerie Moon, Governance Challenges in Global Health, 368 New England J Med (2013) 936-942, March 7, 2013, referring to United Nations Development Programme, Governance for Sustainable Human Development (UNDP, New York, 1997).

103 E.g. UNDP: 'it is ... among other things participatory, transparent and accountable. It is also effective and equitable. And it promotes the rule of law.' (UNDP, 1997).

104 Ibid.

105 Helen Potts, supra note 49; Derick Brinkerhof, Accountability and Health Systems: Toward Conceptual Clarity and Policy Relevance, 19(6) Health Policy and Planning 371-379; more generally, see Mark Bovens, Two Concepts of Accountability: Accountability as a Virtue and as a Mechanism 33(5) West Euro Politics (September 2010) 946-967.
} 
When it comes to health service delivery more specifically, more specific principles include the above-mentioned 'AAAQ', requiring that health services are available, accessible, acceptable and of good quality. ${ }^{106}$

\subsection{Domestic health governance}

States, the primary duty holders under public international law, have certain legal obligations to enhance the health of their population. Based on the right to health, they have the duty to realise the highest attainable standard of health of all individuals residing on their territory (and potentially beyond). They should also realise the other health-related rights as well as the rights of patients. Among other things, this means that the State is under a duty to establish a national public health strategy and plan of action. ${ }^{107}$ For a State to adopt a national public health strategy and plan of action, it must have a properly functioning health system. ${ }^{108}$

To some extent, States have a duty to regulate non-state actors, hence to regulate all the actors in the health sector, varying from (public and private) health insurance companies, hospitals, pharmaceutical companies, to pharmacists, and general practitioners, to the pharmaceutical industry and the food and beverage industry. To bring this back to human rights law: States are under a 'duty to protect' the health and well-being of individuals against the human rights violations of nonstate actors. The (non-binding) General Comment 14 on the Right to the Highest Attainable Standard of Health explains that:

Violations of the obligation to protect follow from the failure of a State to take all necessary measures to safeguard persons within their jurisdiction from infringements of the right to health by third parties. This category includes such omissions as the failure to regulate the activities of individuals, groups or corporations so as to prevent them from violating the right to health of others; the failure to protect consumers and workers from practices detrimental to health, e.g. by employers and manufacturers of medicines or food; the failure to discourage production, marketing and consumption of tobacco, narcotics and other harmful substances; the failure to protect women against violence or to prosecute perpetrators; the failure to discourage the continued observance of harmful traditional medical or cultural practices; and the failure to enact or enforce laws to prevent the pollution of water, air and soil by extractive and manufacturing industries. ${ }^{109}$

\footnotetext{
106 General Comment 14, supra note 47 [12].

107 General Comment 14, supra note 47 [43 (f)].

108 See also, Paul Hunt \& Gunila Backman, Health Systems and the Right to the Highest Attainable Standard of Health, 10(1) Health \& Human Rights (2008) 81-92.

109 General Comment 14, supra note 47 [51].
} 
This paragraph provides many important examples of how the State is entitled to regulate non-state actors in the field of health. At the same time, it is increasingly recognised that the protection and promotion of health involve a shared responsibility, or a multi-stakeholder approach. General Comment 14 recognises that:

\begin{abstract}
While only States are parties to the Covenant and thus ultimately accountable for compliance with it, all members of society - individuals, including health professionals, families, local communities, intergovernmental and non-governmental organizations, civil society organizations, as well as the private business sector - have responsibilities regarding the realization of the right to health $[\ldots] .{ }^{110}$
\end{abstract}

This statement recognises that many different actors have responsibilities under the right to health - setting aside the question of whether such responsibilities are legal or moral in character.

It is interesting to see that, along similar lines, the WHO's legally binding International Health Regulations stipulate that the realisation of the Regulations should be a joint effort, consisting of the State as the primary duty holder and other actors offering support. Based on the Regulations, States are under an obligation to maintain core surveillance and response capacities (Articles 5(1) and 13(1)), while the WHO shall assist States in this task (Articles 5(3) and 13(3)). When requested by the WHO, other States Parties should provide, to the extent possible, support to the WHO-coordinated response activities (Article 13(5)). These international bodies increasingly recognise that a multi-stakeholder approach should be taken to achieve health at the national level.

When it comes to enforcing the health-related instruments, States should ensure that accountability mechanisms are in place to hold responsible actors accountable for their failure to respect and to realise the instruments. It is increasingly recognised that creating accountability for violations of international (human rights) standards is a multi-faceted process which should not rely on (quasi)judicial accountability mechanisms only, but also on a wide range of non-judicial tools, including political, professional, social, financial and administrative accountability mechanisms. ${ }^{111}$ Without discussing these mechanisms in detail, it would be important to facilitate the participation of a wide range of different actors in the implementation

\footnotetext{
110 Ibid [42].
}

111 Mark Bovens, supra note 99, 946-967; Helen Potts, Participation and the Right to the Highest Attainable Standard of Health, University of Essex Human Rights Centre/Open Society Institute <http://repository. essex.ac.uk/9714/1/participation-right-highest-attainable-standard-health.pdf $>$ accessed November 2015. 
process of the instruments under international health law, including civil society groups, the media, national parliaments and professional societies. An example of a case where there was considerable cross-fertilization between civil society and the court system is the well-known Treatment Action Campaign case, which addressed access to an anti-retroviral drug in South Africa. After a broad campaign by the Treatment Action Campaign, the matter was put before the South African Constitutional Court which decided that the unavailability of the drug to the population at large violated the right to health in the Constitution of South Africa. ${ }^{112}$

The Framework Convention on Tobacco (FCTC) has featured in cases before several domestic courts, including in Australia, Peru and the Netherlands. ${ }^{113}$ In September 2014, the Dutch Youth Smoking Prevention Foundation started legal proceedings against the Kingdom of the Netherlands to 'end the structural and excessive influence exerted by the tobacco lobby on government anti-smoking policies'. The case was based on Article 5(3) of the FCTC and the ensuing guidelines, which require States Parties to protect their anti-tobacco policies from commercial and other vested interests of the tobacco industry. ${ }^{114}$ In addition, the case relied on the right to health in the Dutch Constitution and international treaties that the Netherlands is a party to. This case creates an interesting precedent for similar cases in which the interests of public health are balanced against the interests of international trade.

A new case law digest on 'health and human rights' provides many interesting examples of cases addressed at the domestic level, before judicial and quasi-judicial bodies, from different parts of the world. ${ }^{115}$ It turns out that most successful cases have involved access to essential services and medicines. ${ }^{116}$ While most cases occurred in Latin American countries, South Africa and India, domestic courts in Western states are

112 Constitutional Court of South Africa, Minister of Health v. Treatment Action Campaign (TAC), 2002(5) SA 712 (CC).

113 British American Tobacco Australasia Limited and Others $v$ the Commonwealth of Australasia, Case S389/ 2411 <http://www.hcourt.gov.au/cases/case-s389/2011> accessed November 2015. Peruvian Constitutional Tribunal, Jaime Barco Rodas, Unconstitutionality Claim of Article 3 of Law 28705, July 19, 2011, see the Global Health and Human Rights Law Database <http://www.globalhealthrights.org > accessed November 2015. See also Gostin, supra note 10, 235, 267.

114 Unfortunately, the Court of First Instance of The Hague rejected the case on 9 November 2015 (C/ 09/475711/HA ZA 14-1193 <http://uitspraken.rechtspraak.nl/inziendocument?id=ECLI:NL:RBDHA:2015: 12746> Accessed November 2015). For a brief discussion see this author's blog post $<$ https://ghlgblog. wordpress.com/2015/11/12/ court-decision-in-the-case-concerning-the-close-ties-between-the-dutch-governmentand-the-tobacco-industry-november-9th-2015-no-violation-of-article-53-fctc/> accessed November 2015.

115 O’Neill Institute, Global Health and Human Rights Law Database, supra note 113.

${ }^{116}$ HV Hogerzeil \& ors, Is access to essential medicines as part of the fulfillment of the right to health enforceable through the courts? 22(368) Lancet (2006) 305. 
still reluctant to adjudicate cases on the basis of the health-related rights. Such cases set important examples on domestic judicial enforcement of the right to health and other health-related international instruments and norms. ${ }^{117}$

\subsection{Global health governance}

The primary intergovernmental body in the global health field is the WHO. However, due to increasing globalisation, the WHO has now been joined by many players. ${ }^{118}$ Other organisations that play a role in international governance for health include the International Labour Organization (the ILO), the United Nations Development Programme (the UNDP), the United Nations Children's Fund (the UNICEF), the Global Fund for AIDS, Malaria and Tuberculosis, the World Bank and the International Monetary Fund (the IMF), regional development banks and the World Trade Organization. Important private actors are the pharmaceutical industry, the Bill and Melinda Gates Foundation, a wide range of public-private partnerships which have been established to address infectious diseases, as well as NGOs including Médecins sans Frontières and Oxfam. ${ }^{119}$ In relation to disaster relief and humanitarian assistance in times of emergencies specifically, the Office of the United Nations High Commissioner for Refugees, the International Committee of the Red Cross/Red Crescent and the UNICEF, as well as non-governmental organisations and national medical associations, are of particular importance, including assistance to refugees and internally displaced persons play an important role. ${ }^{120}$

While these new organisations bring in important new experiences and resources, the existence of so many organisations together also creates a considerable level of miscommunication and a lack of adequate leadership and accountability. ${ }^{121}$ As the central organisation for international governance for health, the WHO is to play a key

\footnotetext{
117 See also Thérèse Murphey, Health and Human Rights (Hart, Oxford/Portland/Oregon, 2013); Toebes et al, supra note 13, 31-33 \& 49-52.

118 Jennifer Prah Ruger \& Derek Yach, The Global Role of the World Health Organization, II(2) Global Health Governance (Fall 2008/Spring 2009) 1. See also Gostin, supra note 10, 129.

119 General Comment 14, supra note 45 [66]; Jennifer Prah Ruger and Derek Yach, The Global Role of the World Health Organization, 2(2) Global Health Governance (2008-2009) 3.

${ }^{120}$ General Comment 14, supra note 47 [66].

121 Gostin, supra note 10, 129.
} 
role in coordinating these different organisations. ${ }^{122}$ However, the WHO has frequently been criticised for failing to show leadership in this regard. ${ }^{123}$ More specifically during the 2014 Ebola crisis, the WHO was criticised for downplaying the situation and for failing to demonstrate leadership in addressing the outbreak. ${ }^{124}$ It should also be noted that the WHO lacks sufficient resources to address such global health problems. ${ }^{125}$ While fees paid by Member States are limited, voluntary contributions declined after the economic crisis. $^{126}$

To address the global health governance deficit, several scholars and civil society organisations have called for a strengthening of the WHO, for more standard-setting in global health and for more resources to address global health problems. ${ }^{127}$ When it comes to adopting legal instruments, a global coalition of civil society and academics - the Joint Action and Learning Initiative on National and Global Responsibilities for Health (JALI) - has formed an international campaign to advocate for a Framework Convention on Global Health $(\mathrm{FCGH}) .{ }^{128}$ Alongside this initiative it has been suggested that an international fund for health should be established which would ensure that there are sufficient resources to take effective international measures. ${ }^{129}$ Ooms and Hammonds have argued in favour of a Global Fund for Health (along the lines of the existing Global Fund for AIDS) which would allow for the monitoring of contributions of all high income countries to ensure that all countries in need of assistance would receive aid, provided that they have made 'best efforts'. ${ }^{130}$ These initiatives are evidence of a growing wish to boost the global efforts towards health protection.

\footnotetext{
122 Ruger \& Yach, supra note $118,1$.

123 Inter alia, Gostin, supra note 10, 114-128.

124 World Health Organization Heal thyself, The Economist (December 13-19, 2014) 15-18.

125 Gostin, supra note 10, 123-124.

126 The Economist, supra note 124, 18.

127 Gostin \& Taylor, supra note 2, 60; Aginam,supra note 23; Benjamin Mason Meier, The World Health Organization, the Evolution of Human Rights, and the Failure to Achieve Health for All, in, John Harrington \& Maria Stuttaford (eds) Global Health and Human Rights (Routledge, Abingdon, 2010) 163-189. Benjamin Mason Meier, The Highest Attainable Standard: The World Health Organization, Global Health Governance, and the Contentious Politics of Human Rights (PhD thesis) (ProQuest Dissertations PublishingColumbia University, Ann Arbor, 2009).

128 Jali <http://www.jalihealth.org/> accessed November 2015. See also Lawrence O Gostin et al, A Framework Convention on Global Health, 91 Bulletin of the World Health Organization (2013) 790-793.

129 Lawrence O Gostin, Towards an International Health Systems Fund, The Lancet (2014) 1-3.

${ }^{130}$ G Ooms \& R Hammonds, Taking up Daniels' Challenge: The case for Global Health Justice, 12 Health and Human Rights (2010) 3, 29-46, 12.
} 


\section{International health law: challenges for an emerging field}

This article has attempted to bring coherence to the international standard-setting instruments and norms relevant to health. It has been done to outline the content and the scope of international health law as an emerging branch of international law. The article has shown that international health law consists of a set of disjointed health-related instruments that have been adopted within the framework of various international organisations, including the WHO, human rights treatymonitoring bodies and the ICRC.

The implementation and enforcement of international health law remain a huge challenge. A major difficulty will be in bringing coherence to a field that is very broad and relies on instruments and norms from various branches of international law. While it is important to recognise many dimensions of health and, as such, to go beyond mere 'physical well-being' and the 'absence of disease', there is a danger that, as a result of this approach, the field becomes too broad and thus loses its effectiveness and overall significance. In this context it has been suggested that the 'right to health' could be recognised as the key unifying standard in the field of international health law. It would place the health-related interests of individuals at the centre of the debate. While this norm has many flaws, it currently seems to be the best available standard, with its emphasis on health justice and equity.

In addition to bringing coherence to existing instruments, it has been suggested that new standard-setting instruments could be adopted under international health law. In this context, I suggest that WHO, as the main intergovernmental body in the field of health, should make more effective use of its standard-setting capacity. ${ }^{131}$ An initiative that aims to advance global justice in health more generally is the proposed Framework Convention on Global Health. While it raises many conceptual and legal questions, many of them difficult to realise, it nonetheless forms an important call on States and the international community to address the vast health inequalities that exist in our world today. ${ }^{132}$ Along the lines of the FCTC, more specific new instruments could focus on such issues as the world obesity pandemic and the related responsibilities of the food and beverage industries.

\footnotetext{
131 See also Aginam, supra note 25.

132 Jali <http://www.jalihealth.org/> accessed November 2015; See also Global Health Governance, Special Issue: The Framework Convention on Global Health, January 28, 2016, available at <http:// ilreports.blogspot.nl/2016/01/special-issue-framework-convention-on.html>.
} 
Finding ways to move beyond the State-centred nature of public international law and international health law more specifically remains a challenge. In the protection of health, globally and locally, many state and non-state actors interact with each other forming a complex relationship. Additionally, the WHO might play a role in enhancing transparency and accountability among all the actors involved.

Implementation of the instruments at the domestic level is certainly a major goal. Adoption of good-quality health legislations at the domestic level might serve a good start. Countries can learn from the Indian court's ruling in the Novartis case. A purported international health law can play an important role by framing the key norms and principles that 'good' domestic health legislation should reflect. ${ }^{133}$ Scholars and international non-governmental institutions, in particular the WHO, could make a concerted effort to develop domestic model legislation for the health field, in light of the international legal standards. ${ }^{134}$ This domestic model legislation could focus on, inter alia, access to essential medicines and access to maternal and obstetric care, but also on social health insurance and/or social determinants for health such as food standards like sugar and salt intake.

Open Access This article is distributed under the terms of the Creative Commons Attribution 4.0 International License (http://creativecommons.org/licenses/by/4.0/), which permits unrestricted use, distribution, and reproduction in any medium, provided you give appropriate credit to the original author(s) and the source, provide a link to the Creative Commons license, and indicate if changes were made.

${ }^{133}$ Hans V Hogerzeil, Essential Medicines and Human Rights: What Can They Learn from Each Other?, 84 Bulletin of the World Health Organization (2006) 371-375; Amir Attaran et al, Health by Law: The Missed Opportunity to Use Laws for Public Health, 379 The Lancet (2012) 283-85; DC Jayasuriya, Regulation of pharmaceuticals in developing countries, (WHO, Geneva, 1985) <http://whqlibdoc.who.int/publications/ 1985/9241560894_eng.pdf> accessed November 2015.

${ }^{134}$ See also the ELMA project at the University of Groningen <http://www.rug.nl/research/groningencentre-for-law-and-governance/onderzoekscentra/ghlg/elma?lang=en> accessed December 2015. 